\title{
Fire Detectors Arrangement in Objects with Slope Roof
}

\author{
RADOJE B. JEVTIĆ, School of Electrical Engineering „Nikola Tesla“, Niš
}

\author{
Review paper \\ UDC: 614.842 .4 \\ DOI: $10.5937 /$ tehnika1605774J
}

Fire detectors present very important elements of all real time fire protection systems. Their assortment, type and arrangement in object present very important task in sense of fire protection system design. This task is often regulated by proper standards. However, some special cases where some changes in standards and design are necessary and obligated, could be found. This paper has written to presents simulation results of heat and smoke detectors reactions in case of object with slope roof.

Key words: fire, arrangement, simulation, object, slope, roof

\section{INTRODUCTION}

The main purpose of fire protection systems is to provide reliable warning for user in order to avoid human victim and material properties destruction. The design of fire protection systems purports cognition of enormous numbers of facts related to object purpose, objects dimensions, objects ambient conditions, detectors type, and lot of other factors. The final and the most important results of the fire protection systems design are the right choice of fire detectors and their proper arrangement inside the object because fire presents very unpredictable and hard controlled occurrence, such as presented on figure 1.

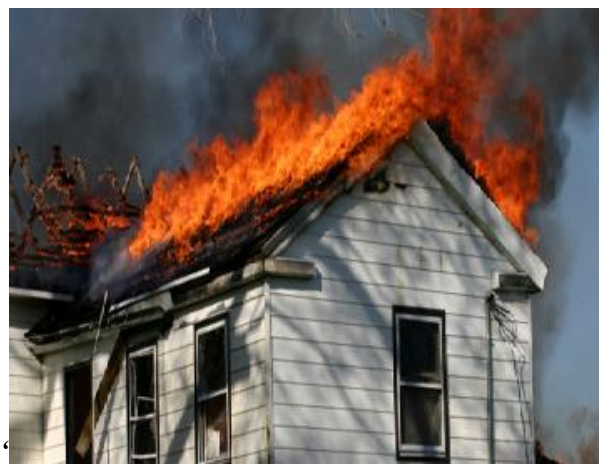

Figure 1 - An example of fire in the house with slope roof, (figure source: http://www.todayshom eown-er.com/video/home-fire-safety-andenergy-efficiency-tips/)

Author's address: Radoje Jevtić, School of Electrical Egineering „Nikola Tesla“, Niš, Aleksandra Medvedeva 18

Papaer received: 07.09.2016.

Paper accepted: 29.09.2016.
Fire detectors could be divided on several ways, according to the way of response, reset possibilities, montage possibilities, the way of resetting, number of states and others.

Fire detectors arrangement into an object is defined according to the proper rules and standards (for example, BS (British Standard), NFPA (National Fire Protection Association), $\quad$ 88-2001 ( ормы пож рной безоп сности), DIN VDE 0833-2 and others). Generally, in the ideal case, the needed fire detectors arrangement and number could be gained as a quotient between supervised surface and detector's supervised surface.

There are lots of other factors that should be considered, such as shape and slope of the roof, barriers, girt, walls positioning, installation positioning, wholes into the walls positions, room height etc. Detectors should be easy visible and accessible, because of its testing and repairing.

The reduction of the range between detectors leads that the system sensibility becomes higher. But, in many cases, the increment of fire detectors number over some optimal limit brings small gain according to the price of the system.

According to noted facts, it is important to find an optimal relation between performance increments and price needed for that.

It is obvious that the problem of fire detectors choice and their arrangement depends of many different factors that could be found in the particular design task for some particular object. Before considering about many special factors, it is important to start from some the most general recommendations. Some of them are presented in table 1 . 
Table 1. Recommendations for detector's choice (table source: Blagojević, Đ. M.: Alarm systems)

\begin{tabular}{|c|c|c|}
\hline Detectors type & Application & No application \\
\hline $\begin{array}{l}\text { Ionization } \\
\text { detectors }\end{array}$ & $\begin{array}{l}\text { Best for } \\
\text { flammable fires }\end{array}$ & $\begin{array}{l}\text { Ambient with } \\
\text { smoke, fumes or } \\
\text { dust }\end{array}$ \\
\hline Optical detectors & $\begin{array}{l}\text { Best for } \\
\text { smouldering fires }\end{array}$ & $\begin{array}{l}\text { Ambient with } \\
\text { smoke, fumes or } \\
\text { dust }\end{array}$ \\
\hline $\begin{array}{l}\text { Multi sensors } \\
\text { (optical+thermal) }\end{array}$ & $\begin{array}{l}\text { Detector of } \\
\text { general purpose }\end{array}$ & $\begin{array}{l}\text { Ambient with } \\
\text { smoke, fumes or } \\
\text { dust }\end{array}$ \\
\hline Linear(beam) & $\begin{array}{l}\text { Huge and high } \\
\text { rooms }\end{array}$ & $\begin{array}{l}\text { Ambient with } \\
\text { smoke, fumes or } \\
\text { dust }\end{array}$ \\
\hline $\begin{array}{l}\text { Thermo } \\
\text { differential }\end{array}$ & $\begin{array}{l}\text { Ambient with } \\
\text { smoke, fumes or } \\
\text { dust }\end{array}$ & $\begin{array}{l}\text { Ambient with } \\
\text { fast temperature } \\
\text { changes or with } \\
\text { temperatures } \\
\text { above } 43^{\circ} \mathrm{C}\end{array}$ \\
\hline $\begin{array}{l}\text { Thermal, fixed } \\
\text { temperature ( } 58 \\
\left.{ }^{\circ} \mathrm{C}\right)\end{array}$ & $\begin{array}{l}\text { Ambient with } \\
\text { smoke, fumes or } \\
\text { dust or with fast } \\
\text { temperature } \\
\text { changes }\end{array}$ & $\begin{array}{l}\text { Ambient with } \\
\text { temperatures } \\
\text { above } 43{ }^{\circ} \mathrm{C}\end{array}$ \\
\hline $\begin{array}{l}\text { Thermal, fixed } \\
\text { temperature ( } 78 \\
{ }^{\circ} \mathrm{C} \text { ) }\end{array}$ & $\begin{array}{l}\text { Ambient with } \\
\text { smoke, fumes or } \\
\text { dust or with } \\
\text { temperatures } \\
\text { above } 43{ }^{\circ} \mathrm{C}\end{array}$ & $\begin{array}{l}\text { Ambient with } \\
\text { temperatures } \\
\text { above } 70{ }^{\circ} \mathrm{C}\end{array}$ \\
\hline
\end{tabular}

This paper has written to present simulation results of heat and smoke detectors in house with slope roof for different burner's positions in order to confirm theoretical noted facts given by proper standards and regulates $[1,2,3,6,8]$.

\section{THE ARRANGEMENT OF FIRE DETECTORS IN SPECIAL CASES}

As a special cases for fire arrangement, it could be considered stairs, girts, galleries, objects with slope roof, downcast or duplicate roofs and similar cases.

The basic rule for fire detectors arrangement in the rooms with slope roofs is that the arrow of detectors is set in the vertical plane of the top-the highest point of the room. According to some rules, as the slope roof could be considered roof with slope that is bigger than $15^{\circ}$, while in general case, it is need to observe relation $h_{1} / a$, as it is presented on figure 2 . If that relation is bigger than 0.2 , the roof is considered on the same way as slope roof.

For western standards, the rules for detectors arrangement are quite different. The recommendation of those standards is that detectors should be positioned on the top point of the room with minimal distance from vertical wall of $50 \mathrm{~cm}$. For example, the recommendations of the NFPA 72 standard are simpler then European standard. According to general recommendation, fire detectors should be positioned on that way that the complete distance of tilts from detectors is less than $0.9 \mathrm{~m}$. If below the roof exist some girts then the relation between girt's depth and roof's height with one side, and relation of distance between girts and roof's height must be observed [1, 2, $10]$.

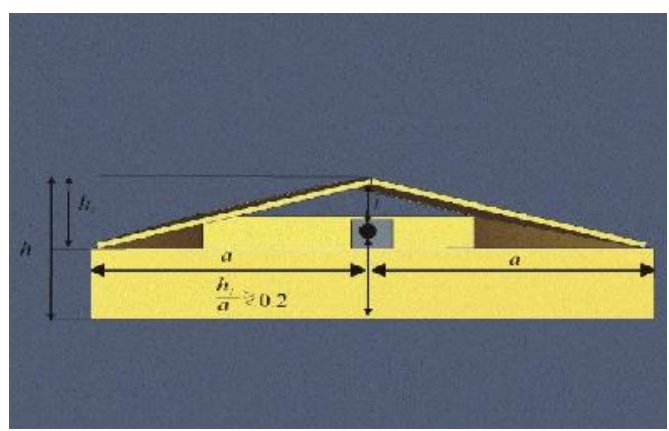

Figure 2 - An example of the room with slope roof with marked dimensions

\section{SIMULATION MODEL}

Simulation model for this paper was created in PyroSim software, version 2016. PyroSim is a power graphical user interface for the Fire Dynamics Simulator (FDS). FDS models can predict smoke, temperature, carbon monoxide, and other substances during fires such as different fire situations and scenarios [11].

Simulation model used for this purpose implied object with slope roof with dimensions $20 \mathrm{~m} \mathrm{x} 40 \mathrm{~m} \mathrm{x}$ $5.5 \mathrm{~m}$. The fire source was modelled as burner with dimensions of $1 \mathrm{mx} 1 \mathrm{~m}$ and HRR (Heat release rate per area) of 50,250 and $500 \mathrm{~kW} / \mathrm{m}^{2}$. The burner's positions were in the corner of the room (the first scenario) and in the middle of the room (the second scenario). The positions for smoke and heat detectors in the objects were according to noted rules. Simulation model in PyroSim with arrangement of detectors and burners are presented on figures from 3 to 6 .

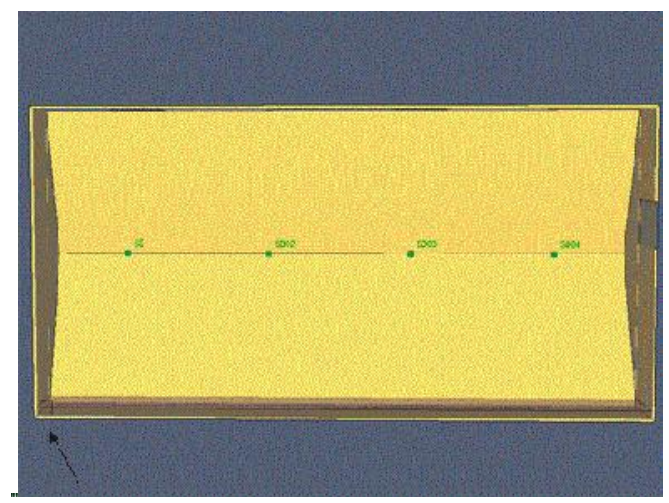

Figure 3 - 3D object in PyroSim with marked burner position in the corner and positioned smoke detectors 


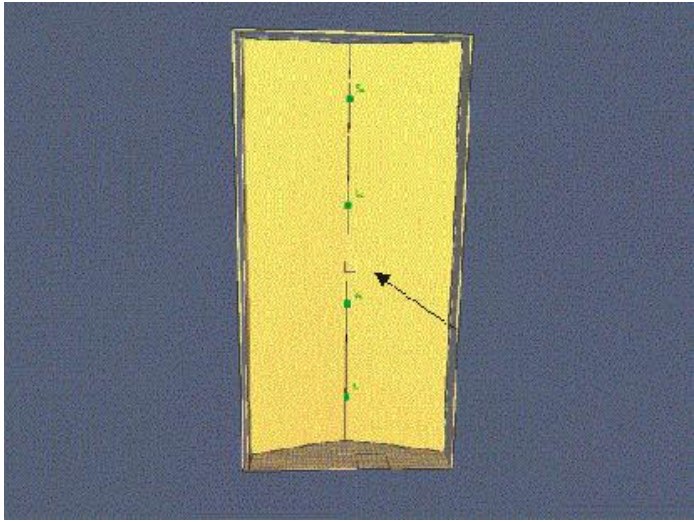

Figure 4 - 3D object in PyroSim with marked burner position in the middle and positioned smoke detectors

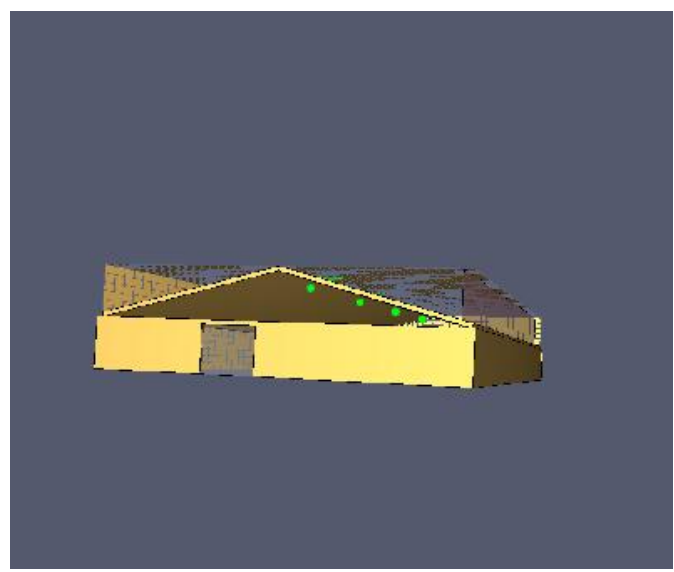

Figure 5 - 3D object in PyroSim with smoke detectors arrangement

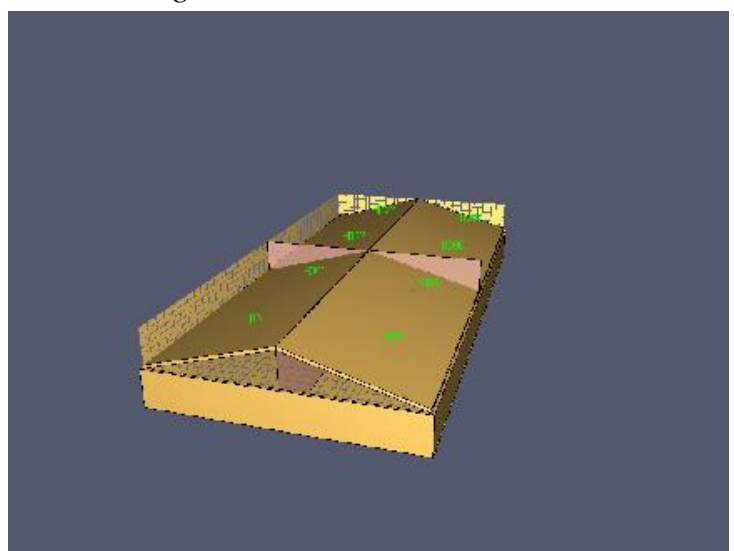

Figure 6 - 3D object in PyroSim with heat detectors arrangement

The reaction temperature for heat detectors was 75 ${ }^{\circ} \mathrm{C}$ (for both simulation models) and the response time index (RTI) was $100 \mathrm{~m}^{1 / 2} \mathrm{~s}^{1 / 2}$, while the activation threshold for smoke detectors was 3,28\% of obscuration (for both simulation models).

Smoke detectors were positioned in one row in vertical plane of the top roof's point, while heat detectors were positioned in two rows.

\section{SIMULATION AND SIMULATION RESULTS}

The simulations were realized on laptop Lenovo IdeaPad G50-80 80E502F3YA, with Intel Core i5$5200 \mathrm{U}$ processor (2 cores, $2.20 \mathrm{GHz}, 3 \mathrm{MB}$ cache), DDR3L memory controller (up to $1600 \mathrm{MHz}$ ), Intel Turbo Boost $2.0(2.70 \mathrm{GHz})$ and 8GB of DDR3 RAM. The simulation time was set on 300 seconds for every simulation. The duration of complete simulation on computer could take some time, depended of simulation model complexity, simulation numerical options, simulation graphical options and hardware computer configuration.

Simulation results for smoke detectors from the first scenario, where the burner was in the corner of the room, and the burner's HRR were 50, 250 and 500 $\mathrm{kW} / \mathrm{m}^{2}$ are presented on figures from 7 to 12 .

Simulation results for smoke detectors from the second scenario, where the burner was in the middle of the room, and the burner's HRR were 50, 250 and 500 $\mathrm{kW} / \mathrm{m}^{2}$ are presented on figures from 13 to 18 .

At the same way, simulation results for heat detectors from the first scenario are presented on figures from 19 to 24 while simulation results for heat detectors from the second scenario are presented on figures from 25 to 30 , for the same burner's positions and HRR [4].

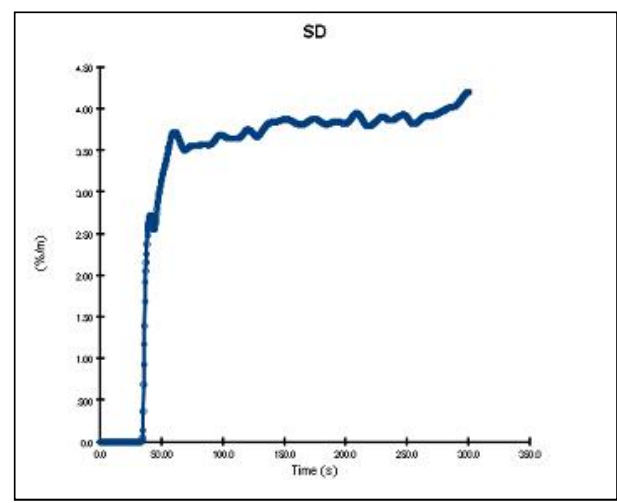

Figure 7 - Simulation results for the nearest smoke detector for burner with HRR of $50 \mathrm{~kW} / \mathrm{m}^{2}$

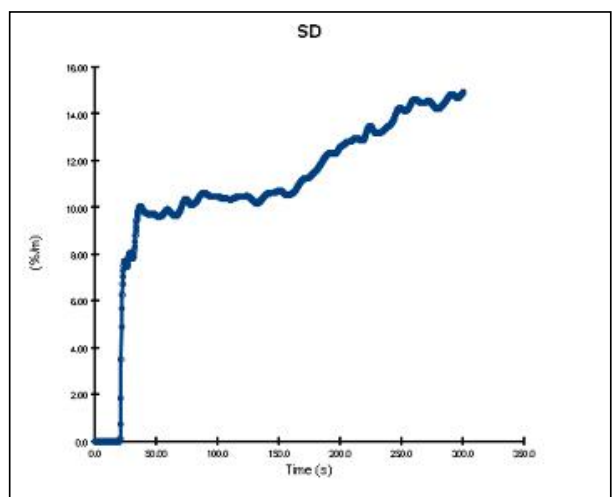

Figure 8 - Simulation results for the nearest smoke detector for burner with HRR of $250 \mathrm{~kW} / \mathrm{m}^{2}$ 


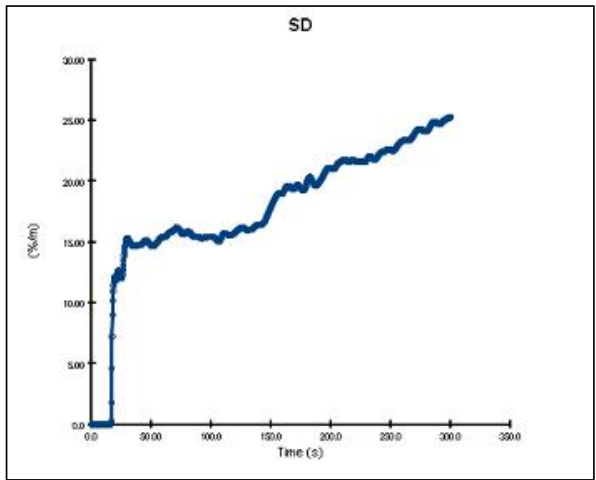

Figure 9 - Simulation results for the nearest smoke detector for burner with HRR of $500 \mathrm{~kW} / \mathrm{m}^{2}$

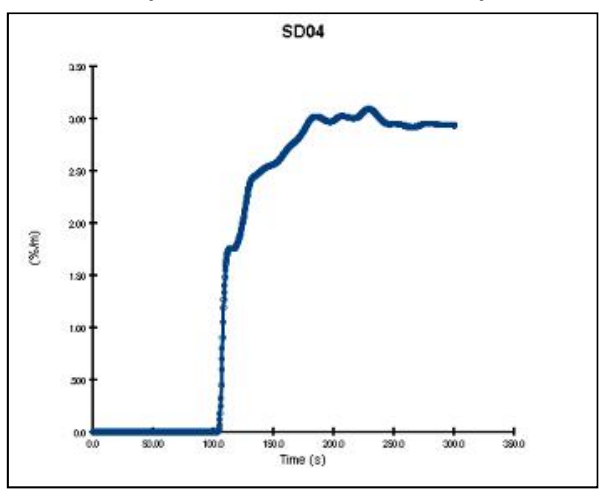

Figure 10 - Simulation results for the farthest smoke detector for burner with HRR of $50 \mathrm{~kW} / \mathrm{m}^{2}$

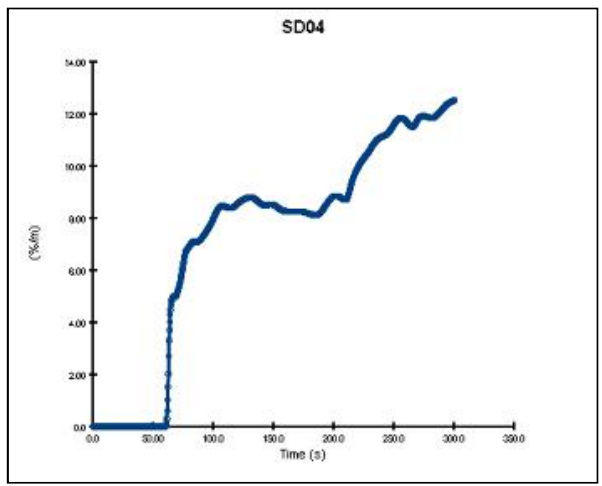

Figure 11 - Simulation results for the farthest smoke detector for burner with HRR of $250 \mathrm{~kW} / \mathrm{m}^{2}$

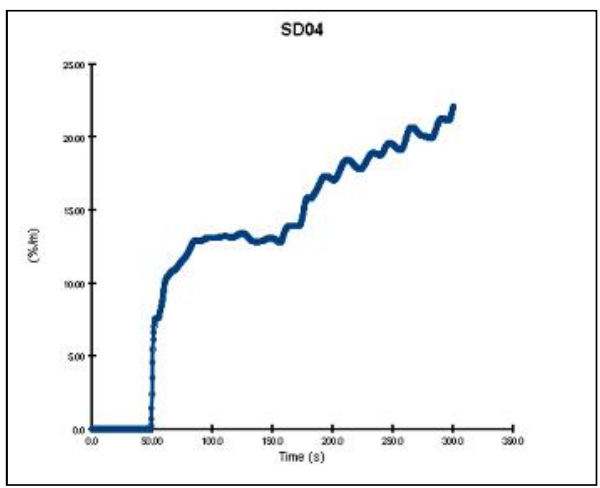

Figure 12 - Simulation results for the farthest smoke detector for burner with HRR of $500 \mathrm{~kW} / \mathrm{m}^{2}$

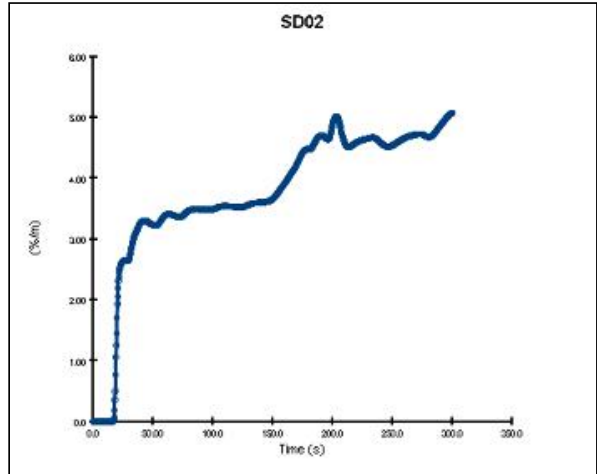

Figure 13 - Simulation results for the nearest smoke detector for burner with HRR of $50 \mathrm{~kW} / \mathrm{m}^{2}$

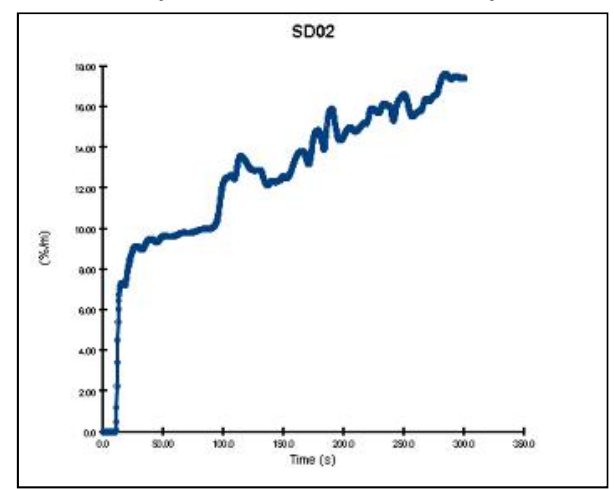

Figure 14 - Simulation results for the nearest smoke detector for burner with HRR of $250 \mathrm{~kW} / \mathrm{m}^{2}$

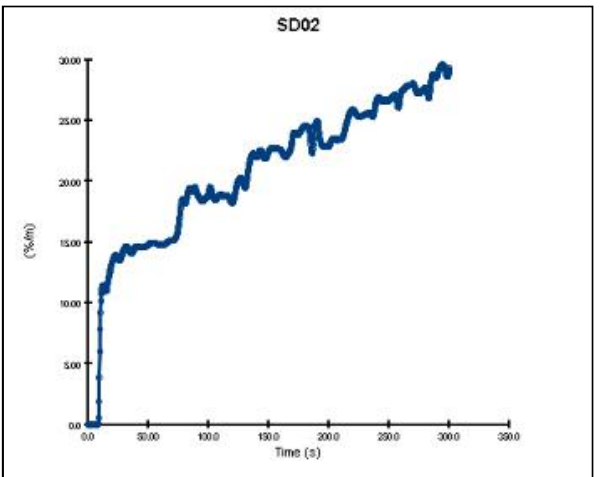

Figure 15 - Simulation results for the nearest smoke detector for burner with HRR of $500 \mathrm{kW/ \textrm {m } ^ { 2 }}$

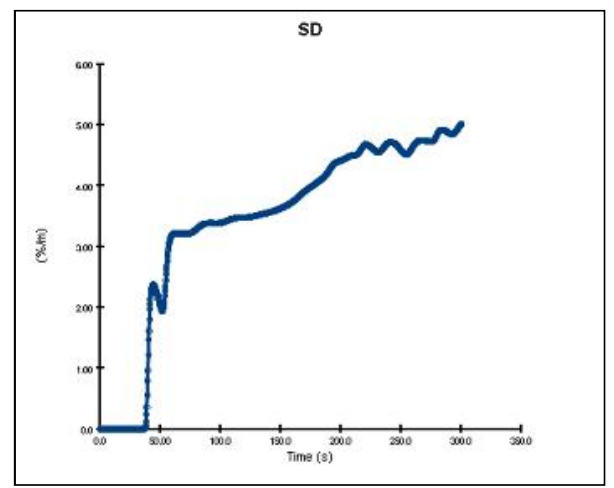

Figure 16 - Simulation results for the farthest smoke detector for burner with HRR of $50 \mathrm{~kW} / \mathrm{m}^{2}$ 


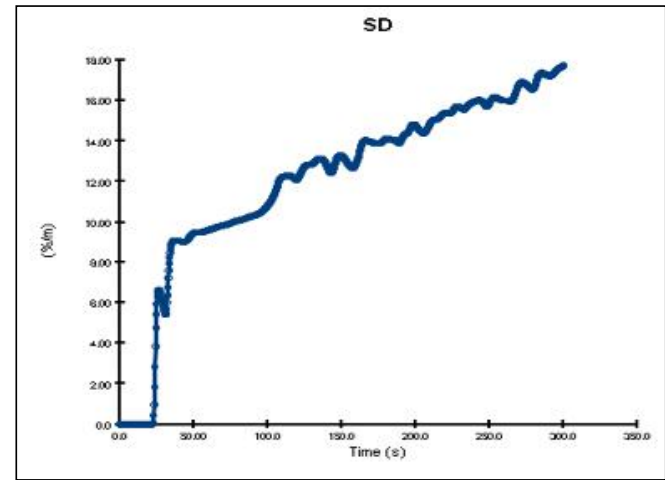

Figure 17 - Simulation results for the farthest smoke detector for burner with HRR of $250 \mathrm{kW/ \textrm {m } ^ { 2 }}$

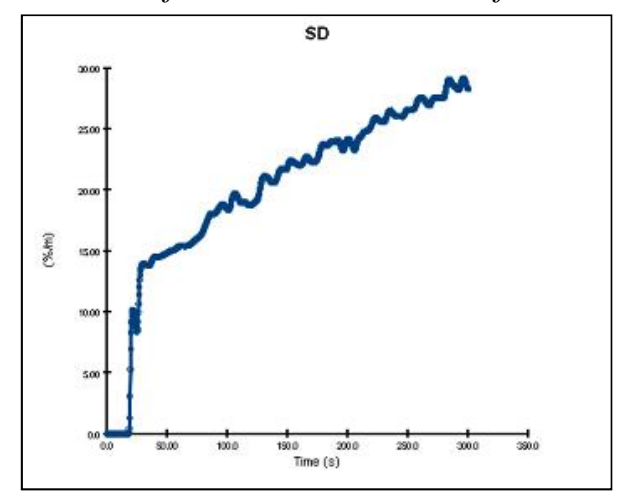

Figure 18 - Simulation results for the farthest smoke detector for burner with HRR of $500 \mathrm{~kW} / \mathrm{m}^{2}$

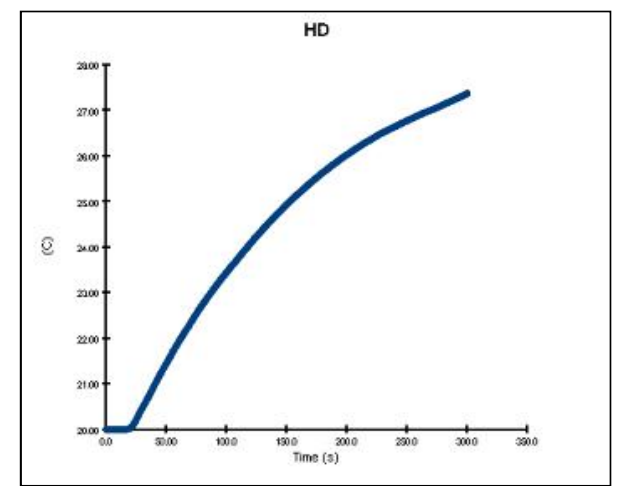

Figure 19 - Simulation results for the nearest heat detector for burner with HRR of $50 \mathrm{kW/ \textrm {m } ^ { 2 }}$

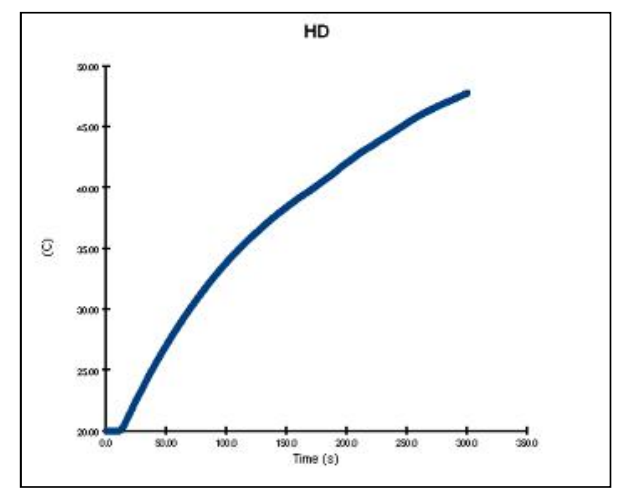

Figure 20 - Simulation results for the nearest heat detector for burner with HRR of $250 \mathrm{~kW} / \mathrm{m}^{2}$

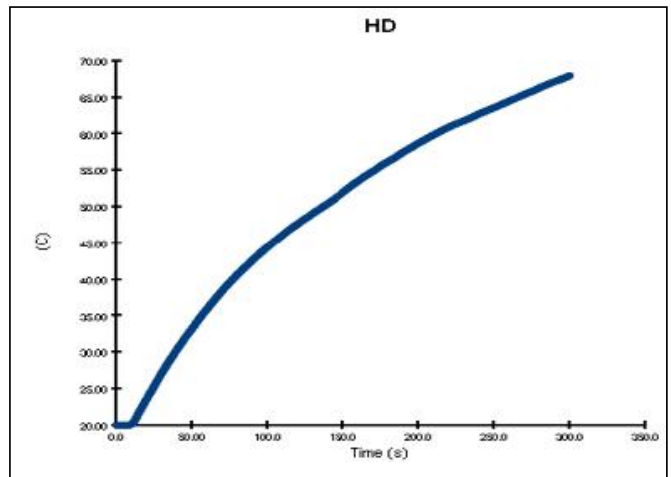

Figure 21 - Simulation results for the nearest heat detector for burner with HRR of $500 \mathrm{kW/m} \mathrm{m}^{2}$

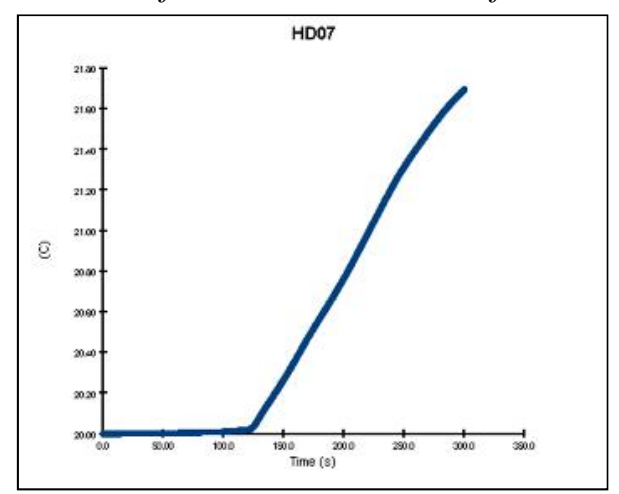

Figure 22 - Simulation results for the farthest heat detector for burner with HRR of $50 \mathrm{~kW} / \mathrm{m}^{2}$

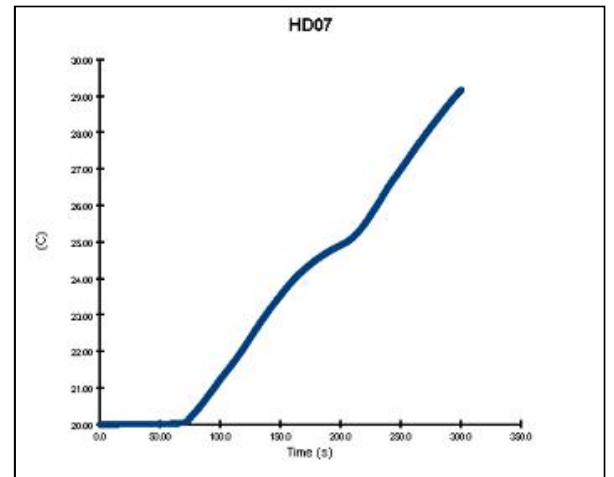

Figure 23 - Simulation results for the farthest heat detector for burner with HRR of $250 \mathrm{~kW} / \mathrm{m}^{2}$

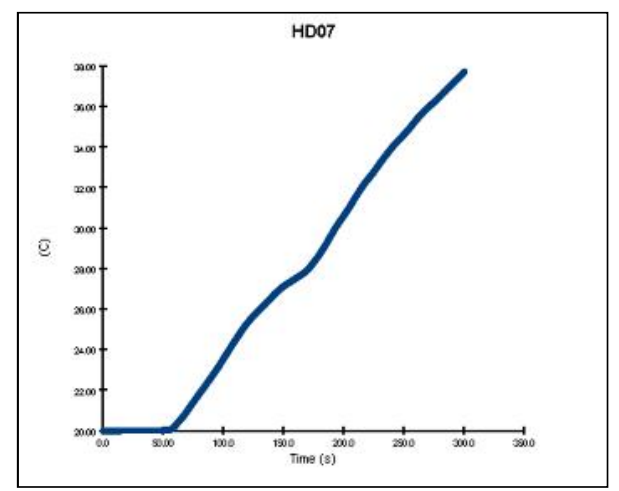

Figure 24 - Simulation results for the farthest heat detector for burner with HRR of $500 \mathrm{~kW} / \mathrm{m}^{2}$ 


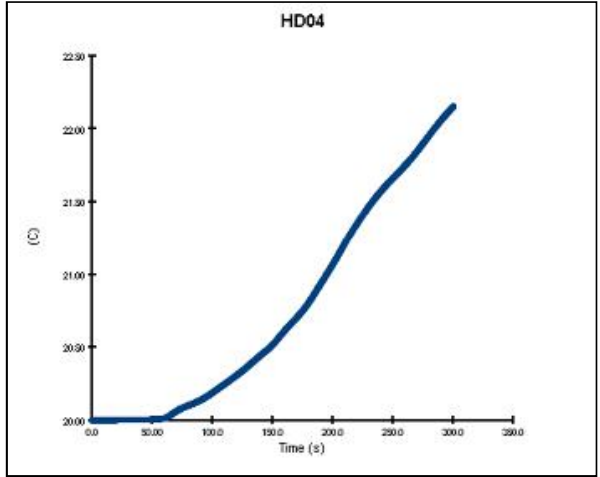

Figure 25 - Simulation results for the nearest heat detector for burner with HRR of $50 \mathrm{~kW} / \mathrm{m}^{2}$

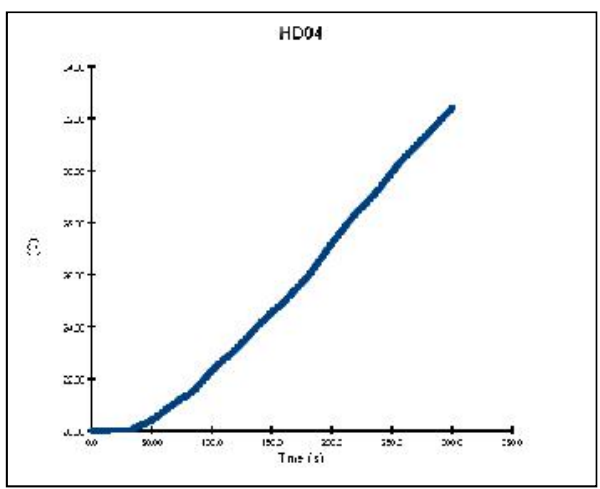

Figure 26 - Simulation results for the nearest heat detector for burner with HRR of $250 \mathrm{~kW} / \mathrm{m}^{2}$

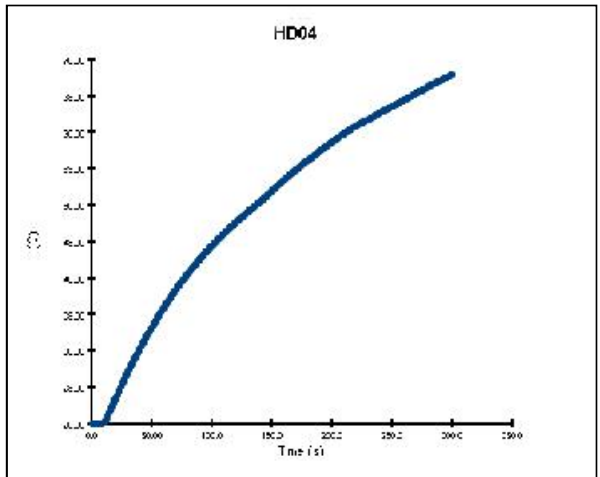

Figure 27 - Simulation results for the nearest heat detector for burner with HRR of $500 \mathrm{~kW} / \mathrm{m}^{2}$

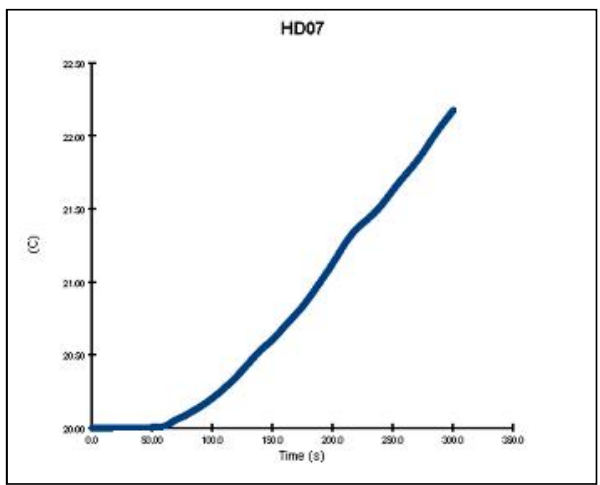

Figure 28 - Simulation results for the farthest heat detector for burner with HRR of $50 \mathrm{~kW} / \mathrm{m}^{2}$

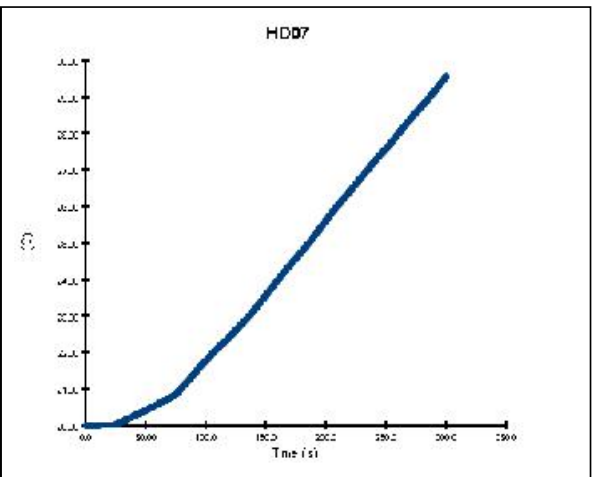

Figure 29 - Simulation results for the farthest heat detector for burner with HRR of $250 \mathrm{~kW} / \mathrm{m}^{2}$

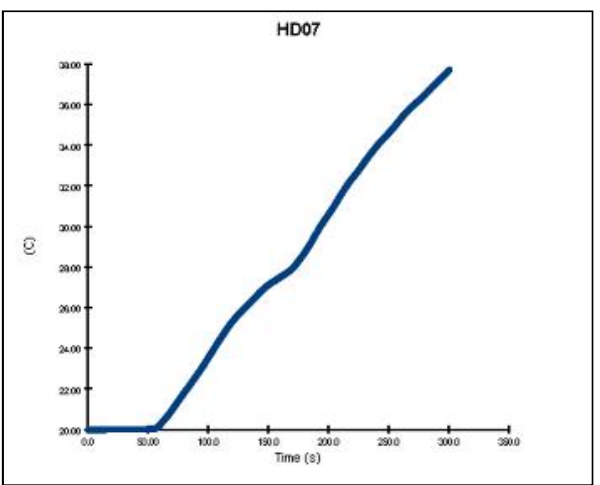

Figure 30 - Simulation results for the farthest heat detector for burner with HRR of $500 \mathrm{~kW} / \mathrm{m}^{2}$

\section{DISCUSSION}

Realized simulation results for the first and the second scenario for smoke detectors presented on figures from 7 to 18 showed that for complete time of 300 seconds every detector will have an alarm reaction. Of course, that depends from the burners HRR and burn material. In any case, theoretical approach for the problem of the object with the slope roof is correct. The complete results for times needed for smoke detectors activation for both scenarios are presented on figure 31 .

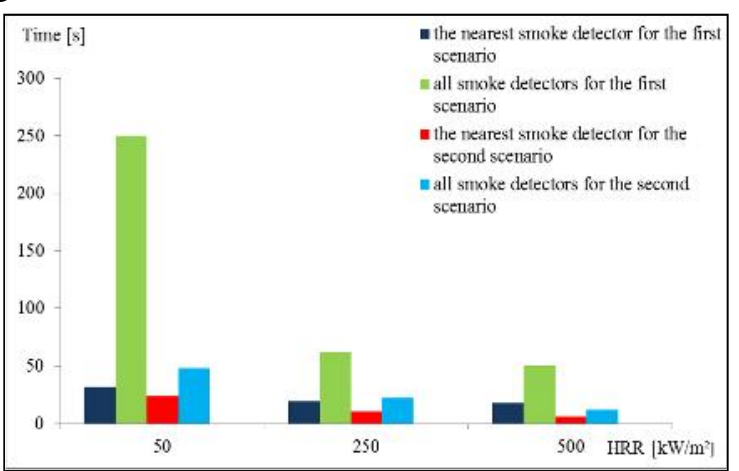

Figure 31 - The complete simulation results for both scenarios

Realized simulation results for the first and the second scenario for heat detectors presented on figures 
from 19 to 30 showed that for complete time of 300 seconds every detector will not have an alarm reaction because none heat detector will react. That was, in real, possible for fires of TF2 and TF3 types, with high concentration of grey and black smoke. It took very short time for fire detectors in HD position for the first scenario or HD04 to react in the case with burner of 500 HRR but it still couldn't reach the response limit of detector $\left(75^{\circ} \mathrm{C}\right)$.

If the time for simulation was longer, the temperature limit of $75^{\circ} \mathrm{C}$ probably would be broken. It can be seen that the simulated object was empty-with more or less other objects (desks, chairs, cupboards or other objects with different fire properties) inside this object with slope roof and the temperature of fire would be much higher than temperature realized by simulation.

Smoke detectors were arranged in one row in vertical plane of the highest object's point. Heat detectors were arranged in two rows in two different planes according to the standards. Simulation showed that, for heat detectors, greater number of heat detectors bring very small or even none effect in sense of faster reaction on temperature. For heat detectors with different properties (different RTI or less temperature limit response from let say, $50{ }^{\circ} \mathrm{C}$, reactions would be more intensive.

\section{CONCLUSION}

Realized simulation results showed and justified potential smoke and heat detectors arrangement for object with slope roof and their reaction times, where all detectors were positioned according to valid rules.

Simulation results for this and every other simulated object could realize were precious information such as the optimal positions for heat detectors, smoke detectors, carbon monoxide detectors, flame detectors and other fire installations, potential evacuation situations and many other benefits on very accurate, relative fast and, what is the most important, safe way.

It simulation software must is obvious according to its benefits that simulation software must be standard "tool" for fire protection engineering and other similar problems. This paper was written to propound usage of simulation software and to confirm theoretical tasks by simulation for fire detectors arrangement in special occasions $[2,5,7,9,10]$.

\section{REFERENCES}

[1] Blagojević Đ. M, Alarm systems, Faculty of occupational safety in Niš, pp. 180,189, 193, ISBN 978-86-6093-025-7, Niš, 2011.

[2] Blagojević Đ. M, Alarm systems-added edition, Faculty of occupational safety in Niš, ISBN 978-866093-070-7, Nǐ̌, 2015.

[3] ISO 7240: Fire detection and alarm systems -- Part 9: Test fires for fire detectors, 2006.

[4] Jevtić B. R, Ničković T. J, The determination of fire propagation by simulation, 58 $8^{\text {th }}$ ETRAN CONFERENCE, Vrnjačka Banja, 2014.

[5] Jevtić B. R, The importance of fire simulation in fire prediction, Tehnika, Vol 1., pp. 153-158, ISSN 00402176, Beograd, 2014.

[6] Jevtić B. R, Selection of the fire detectors and their arrangement in object, Bezbednost, UDK $343+351.74 . / 75(05)$, YU ISSN 0409-2953, Vol 1/2015, pp.197-215, Beograd, Srbija, 2015.

[7] Jevtić B. R, Simulation of evacuation -the case of electrotechnical school laboratory section, Facta Universitatis, Working and Environmental Protection, Vol 12, $\mathrm{N}^{\mathrm{o}} 2$, pp. 253-260, ISSN 0354-804X, Niš, Serbia, 2015.

[8] Jevtić B. R, The evacuation possibilities of sanitary objects , Zdravstvena zaštita, Vol 6., pp. 45-52, YU ISSN 03050-3208, Beograd, Serbia, 2015.

[9] Jevtić B. R, The fire detectors arrangement in rooms with no standard geometgry, Safety Engineering, Vol 6., No. 1., pp. 13-20, ISSN-2217-7124, Niš, Serbia, 2016.

[10]NFPA 72: National Fire Alarm Code, 1999 Edition, NFPA, 1999.

[11]PyroSim user manual, pp. 4, Thunderhead engineering, 2016. 


\section{REZIME}

\section{RASPORED DETEKTORA POŽARA U SLUČAJU OBJEKTA SA KOSIM KROVOM}

Detektori požara predstavljaju veoma važne elemente svih sistema za zaštitu od požara koji rade u realnom vremenu. Njihov odabir, tip $i$ raspored u objektu predstavlja veoma važan zadatak $u$ smislu projektovanja sistema za zaštitu od požara. Ovaj zadatak je često regulisan odgovarajućim standardima. Međutim, postoje specijalni slučajevi gde su promene u standardima nužne i obavezne. Ovaj rad je napisan da prikaže simulacione rezultate reakcija detektora toplote i dima u slučaju objekta sa kosim krovom.

Ključne reči: požar, raspored, simulacija, objekt, kosina, krov 